Jurnal Teknologi, 40(B) Jun. 2004: 27-40

(C) Universiti Teknologi Malaysia

\title{
NEURAL NETWORK MODEL FOR DESIGN CONSTRUCTABILITY ASSESSMENT
}

\author{
ROSLI MOHAMAD ZIN ${ }^{1}$, MUHD. ZAIMI ABD. MAJID ${ }^{2}$, CHE WAN FADHIL \\ CHE WAN PUTRA ${ }^{3} \&$ ABDUL HAKIM MOHAMMED ${ }^{4}$
}

\begin{abstract}
This paper presents an artificial neural network (ANN) technique of analysis for the assessment of design constructability. The multilayer back-propagation neural network model consists of 12 and 1 output variable. The input variables are the level of applications of constructability factors, which are sub-factors of the most important design phase constructability principles while the output variable is the level of design constructability. The development of the model goes through five main stages: identifying the design phase constructability principles, identifying the degree of importance of the constructability principles, formulating a framework for measuring the level of application of constructability principles and design constructability, collecting historical project data, and applying ANN to assess design constructability. Each stage of the model development is described. Historical project data sets related to beam construction have been collected from various contractors that have at least several years of experience in building construction. A total of 78 data sets were used to test and train the network. The determination of the optimum number of hidden nodes, hidden layers, initial weights of the links connecting the nodes, and the number of epochs for training the networks, are normally based on trial and error. The best architecture was found to consist of 12 input nodes, 5 hidden nodes, and 1 output node.
\end{abstract}

Keywords: Artificial neural network (ANN), design contructability, multilayer back-propagation neural network model, constructability factors

\begin{abstract}
Abstrak. Kertas ini memaparkan satu kajian mengenai penilaian kebolehbinaan reka bentuk menggunakan kaedah rangkaian neural tiruan (ANN). Model neural timbalbalik berbilang lapis yang. dihasilkan mengandungi 12 pemboleh ubah input dan 1 pemboleh ubah output. Pemboleh ubah input terdiri dari tahap gunapakai faktor-faktor kebolehbinaan iaitu merupakan subfaktor prinsip-prinsip terpenting kebolehbinaan fasa reka bentuk manakala pemboleh ubah output adalah tahap kebolehbinaan reka bentuk. Pembangunan model dibuat melalui lima peringkat: mengenal pasti prinsip-prinsip kebolehbinaan fasa reka bentuk, menentukan darjah kepentingan prinsip-prinsip kebolehbinaan, menghasilkan satu kerangka untuk mengukur tahap guna pakai prinsip-prinsip kebolehbinaan dan tahap reka bentuk, mengumpul data-data projek terdahulu, dan mengguna pakai kaedah ANN untuk menilai kebolehbinaan reka bentuk. Setiap peringkat pembentukan model adalah diterangkan. Datadata projek terdahulu berkaitan pembinaan rasuk telah dikumpulkan dari kontraktor-kontraktor yang mempunyai pengalaman beberapa tahun dalam pembinaan bangunan. Sejumlah 78 set data telah digunakan untuk melatih dan menguji rangkaian neural. Penentuan bilangan optima bagi nod tersembunyi, aras tersembunyi, pemberat awalan bagi penghubung antara nod, dan bilangan iterasi latihan adalah berdasarkan cubaan dan ralat. Arkitek rangkaian neural terbaik didapati mengandungi 12 nod input, 5 nod tersembunyi dan 1 nod output.
\end{abstract}

Kata kunci: Rangkaian neural tiruan (ANN), kebolehbinaan reka bentuk, model neural timbalbalik berbilang lapis, faktor-faktor kebolehbinaan

${ }^{1,2 \& 3}$ Faculty of Civil Engineering, Universiti Teknologi Malaysia

$4 \quad$ Faculty of Engineering and Geoinformation Science, Universiti Teknologi Malaysia 


\subsection{INTRODUCTION}

The traditional contracting system that is commonly practiced in this country resulted in the design being separated from the construction. The separation of design and construction has led to a lot of problems whereby many problems during construction can be traced back to its design stage. Constructability is seen to be able to solve some of these design-related problems. Constructability or buildability as it is known in the U.K., is the extent to which the design of a building facilitates ease of construction, subjected to the overall requirements for the completed building [1]. The studies by the Construction Industry Institute (CII) in the US and others have demonstrated that improved design constructability has led to better project performance [2-6]. In order to improve design constructability, there are three different groups of constructability improvement methods that can be used by designers: 1) guidelines, 2) computerised systems, and 3) manual methods [7]. The guidelines provide the designer with general recommendations for implementing constructability in projects. These guidelines are intended to stimulate thinking in terms of constructability rather than being a complete checklist. The computerised systems on the other hand, provide designers with an automated assessment of various aspects of constructability such as assembly difficulty [8-10], construction tolerance [11], and construction methods $[12,13]$. The constructability improvement methods based on manual systems are developed with the aim of providing designers with simple procedure to manually evaluate design constructability by using scales or formulae [14]. One of the common characteristics among the improvement methods, especially the computerised systems, is the inability of the developed systems to optimise design based on different aspects of constructability as listed in section 3.1. In view of this problem, the study focuses on developing a model that can be used to assess design constructability based on various aspects of constructability.

\subsection{METHODOLOGY}

The methodologies adopted in this study were through questionnaire survey and model development using Artificial Neural Network (ANN) method. Several important publications related to constructability, especially by the CII of USA [2], CII of Australia [15], and CIRIA [4] were among the main source of information in this study. A review of the literature resulted in the identification of 14 types of designrelated problems in construction and 18 design phase constructability principles [16], and evaluation of the existing constructability improvement methods [7]. The outcomes of this review and the findings from the questionnaire survey exercise form a basis for the development of a beam-design constructability assessment model. 


\subsection{THE DEVELOPMENT OF BEAM-DESIGN CONSTRUCTABILITY ASSESSMENT MODEL}

The development of the constructability assessment model is based on ANN technique of analysis. ANN is a method that has been successfully used for solving various problems in science and engineering. In engineering, ANN has been applied over a wide range of topics such as construction litigation outcome prediction [17], reservoir net inflow forecasting [18], dispute resolution classification [19], organizational effectiveness measurement [20], pre-design stage cost prediction [21], and housing needs [22]. Basically, the most common applications of neural networks are in form of prediction and classification. ANN is a system composed of a large number of highly interconnected processing elements (neurons), which can be configured for specific application, such as pattern rocognition or data classification, through a learning process. ANNs can provide meaningful answers even when the data to be processed include errors or incomplete, and can process information rapidly when applied to solve real world problems [21,23]. ANN can also handle non-linearities in the data. It is also suitable for solving complex cognitive problems. These important properties of neural network have made it suitable for solving the constructability problem described in this study.

Since the focus of the study is to develop a model that is able to take into account different aspects of constructability, it is made possible by relating the level of application of constructability principles during the design process with the level of design constructability. In general, the constructability assessment model consists of two main components: constructability factors and design constructability. The development of the constructability-assessment model for project designs goes through five main stages. The followings describe each stage of the model development:

\subsection{Identifying the Design Phase Constructability Principles}

The identification of the constructability principles that are suitable for implementation during the design phase was done through literature survey from various available publications. A total of 18 design phase constructability principles had been identified. The followings are the summary of the main constructability principles that were identified from this exercise [16].

- Principle P1: Carry out thorough investigation of the site

- $\quad$ Principle P2: Design for minimum time below ground

- $\quad$ Principle P3: Design for simple assembly

- Principle P4: Encourage standardisation/repetition

- Principle P5: Design for preassembly and/or modularisation

- Principle P6: Analyse accessibility of the jobsite 
- $\quad$ Principle P7: Employ any visualisation tools such as 3D CAD to avoid physical interference

- $\quad$ Principle P8: Investigate any unsuspected, unrealistic or incompatible tolerances

- $\quad$ Principle P9: Investigate the practical sequence of construction

- Principle P10: Plan to avoid damage to work by subsequent operations

- Principle P11: Consider storage requirement at the jobsite

- $\quad$ Principle P12: Investigate the impacts of design on safety during construction

- Principle P13: Design to avoid return visit by trade

- Principle P14: Design for the skills available

- Principle P15: Consider suitability of designed materials

- Principle P16: Provide detail and clear design information

- Principle P17: Design for early enclosure

- $\quad$ Principle P18: Consider adverse weather effect in selecting materials or construction methods

\subsection{Identifying the Degree of Importance of Design Phase Constructability Principles}

In order to determine the degree of importance of the design phase constructability principles, a questionnaire survey was conducted [7]. The opinions of the engineers and architects from various organisations were collected from the survey. The results obtained from the questionnaire exercise confirmed that the degrees of importance of principles P1 to P18 are toward the important or very important side. Principles P3 'design for simple assembly', P4 'encourage standardisation/repetition', P5 'design for preassembly and/or modularisation', P6 'analyse accessibility of the job-site', P14 'design for the skills available', and P15 'consider suitability of design materials' are the common principles with a high degree of importance.

\subsection{Formulating a Framework for Measuring the Level of Application of Constructability Principles and Design Constructability}

In order to measure the level of application of constructability principles during the design process, factors under each principle that have significant influence on constructability have been considered. These factors were identified based on the recommendations given in the literature, coupled with information gathered from interviews with experts in the construction industry. Methodology of measuring the level of application of these factors was then formulated. Table 1 provides examples of the identified constructability factors under principle P4 'encourage standardisation/ repetition' and methodology of measuring the level of application of the factors. Similar approach has been used for other principles namely principles P3, P5, P6, P14, 
Table 1 Constructability factors and methods of measuring the level of application

\begin{tabular}{|c|c|c|}
\hline Factors & Measurement & Level of application \\
\hline $\begin{array}{l}\text { 1. Size } \\
\text { (most common) }\end{array}$ & $\begin{array}{l}\% \text { coverage } \\
\text { SI } \mathrm{N} \times 100 \\
\mathrm{SI}-\text { Total number of design elements } \\
\text { under the most common size } \\
\mathrm{N} \text { - Total number of design elements }\end{array}$ & $\begin{array}{ll}\text { Very Low } & \leq 20 \% \\
\text { Low } & >20 \%-40 \% \\
\text { Medium } & >40 \%-60 \% \\
\text { High } & >60 \%-80 \% \\
\text { Very High } & >80 \%\end{array}$ \\
\hline $\begin{array}{l}\text { 2. Shape } \\
\text { (most common) }\end{array}$ & $\begin{array}{l}\text { \% coverage } \\
\mathrm{SH} / \mathrm{N} \times 100 \\
\mathrm{SH}-\text { Total number of design elements } \\
\text { under the most common shape } \\
\mathrm{N} \text { - Total number of design elements }\end{array}$ & $\begin{array}{ll}\text { Very Low } & \leq 20 \% \\
\text { Low } & >20 \%-40 \% \\
\text { Medium } & >40 \%-60 \% \\
\text { High } & >60 \%-80 \% \\
\text { Very High } & >80 \%\end{array}$ \\
\hline
\end{tabular}

and P15. As a result, a total of 12 factors under 6 most important design phase constructability principles were identified. These factors are assembly process, rebar assembly, bay dimensioning, formwork utilisation, size, shape, material, detailing, offsite assembly, location, trade variability, and specifications. Further details of the developed framework can be found from [7].

The measurement of the level of design constructability, on the other hand, is based on the recommendations given by CIRIA [1]. In this study, the level of design constructability is directly related to the ease of construction of the design element being considered. A five-point Likert scale ranging from very good to very poor is used to reflect the level of constructability of the design element. A complete beamdesign constructability assessment framework that has been formulated is as shown in Table 2.

Table 2 Beam-design constructability assessment framework

\begin{tabular}{|c|c|}
\hline Input variables & Measurement \\
\hline P3. Design for simple assembly & \\
\hline 1. Assembly process & $1-5$ (V.Low - V.High) \\
\hline 2. Rebar assembly & $1-5$ (V.Low - V.High) \\
\hline 3. Structural bay dimensioning & $1-5$ (V.Low - V.High) \\
\hline 4. Formwork utilisation & $1-5$ (V.Low - V.High) \\
\hline
\end{tabular}


Table 2 (continue)

\begin{tabular}{|c|c|}
\hline Input variables & Measurement \\
\hline \multicolumn{2}{|c|}{ P4. Encourage standardisation/repetition } \\
\hline 5. $\quad$ Size & $1-5$ (V.Low - V.High) \\
\hline 6. Shape & $1-5$ (V.Low - V.High) \\
\hline 7. Material & $1-5$ (V.Low - V.High) \\
\hline 8. $\quad$ Detailing & $1-5$ (V.Low - V.High) \\
\hline \multicolumn{2}{|c|}{ P5. Design for preassembly/modularisation } \\
\hline 9. Offsite assembly & $1-5$ (V.Low - V.High) \\
\hline \multicolumn{2}{|l|}{ P6. Analyse accessibility of the jobsite } \\
\hline 10. Location & $1-5$ (V.Low - V.High) \\
\hline \multicolumn{2}{|l|}{ P14. Design for the skills available } \\
\hline 11. Trade variability & $1-5$ (V.Low - V.High) \\
\hline \multicolumn{2}{|c|}{ P15. Consider suitability of design materials } \\
\hline 12. Specifications & $1-5$ (V.Low - V.High) \\
\hline \multicolumn{2}{|l|}{ Output Variable } \\
\hline 1. Design constructability & $1-5$ (V.Poor - V.Good) \\
\hline
\end{tabular}

\subsection{Collecting Historical Project Data}

Based on the list of variables and their respective measurements, data were collected from contractors with at least five years of experience in building construction. A total of 78 sets of beam constructability data were collected from this exercise.

\subsection{Applying Artificial Neural Network (ANN) to Assess Beam- Design Constructability}

ANN based modeling process involves five main aspects: 1) data acquisition, analysis, and problem representation; 2) architecture determination; 3) learning process determination; 4) training of the network; and 5) testing of the network for generalization evaluation [22]. ANN functions as an information-processing technique analogous to the effect of the synaptic strength in the biological neuron [24]. Each input is multiplied by a weight, and the sum of all weighted inputs determines the degree of activation level, which is further modified by an activation function to produce the output signal, expressed as $O=f\left(\sum w_{i} x_{i}\right)$, where $O=$ output; $x$ and $w_{i}=i_{t h}$ input and corresponding connection weight; and $f=$ activation function. The connection weights 
between processing elements are updated by applying learning rules or mathematical algorithms. There are a variety of learning rule, which are in common use. The changing of the connection weights (training) causes the network to learn the solution to a problem. The Delta Rule is one of the commonly used algorithms. This rule is based on the idea of continuously modifying the strengths of the input connections to reduce the difference (the delta) between the desired output value and the actual output of a neuron [25]. This algorithm changes the connection weights in the way that minimizes the mean square error of the network. The error is back propagated into previous layers one at a time. The process of back-propagating the network errors continues until the first layer is reached. The network type called Feed forward, Back-propagation (BP) derives its name from this method of computing the error term. In view of the ability of BP network to perform various tasks, coupled with the fact that it is one of the easiest networks to understand, this neural computational technique has been used in the study. Specifically, the Multi-Layer Perceptron (MLP) neural computational technique has been chosen. During training, various ANN training parameters such as number of hidden layers, number of hidden nodes, and transfer functions were investigated before the final network is selected.

\subsubsection{The Network Architecture}

The proposed multilayer perceptron consists of an input layer, which has 12 input variables, a hidden layer, and an output layer with one output variable. Figure 1 illustrates the architecture of the constructability assessment model. Input layer consists of variables related to the degree of application of constructability factors under 6 most important design phase constructability principles. These factors are assembly process, rebar assembly, grid dimensioning, formwork utilisation, size, shape, material, detailing, offsite assembly, location, trade variability, and specifications. On the other side, the output layer consists of one variable, which is the level of design constructability.

\subsubsection{Training and Testing}

According to [26] there is no formal method to derive a network configuration for a given problem. The problem of finding a sensible good set of parameters which include the number of hidden nodes, hidden layers, initial weights of the links connecting the nodes and the number of epochs for training the networks are normally based on trial and error. In this study, the learning algorithm used was the Steepest Descent where the coefficients for the learning rate and momentum are shown in Table 3. These values have been derived by SPSS Inc. [27] based on previous experience in neural network modeling. The same approaches to determine the learning rate and momentum coefficients have also been used in several other studies [18, 23]. The coefficients for the learning rate and momentum are changing at each stage of 


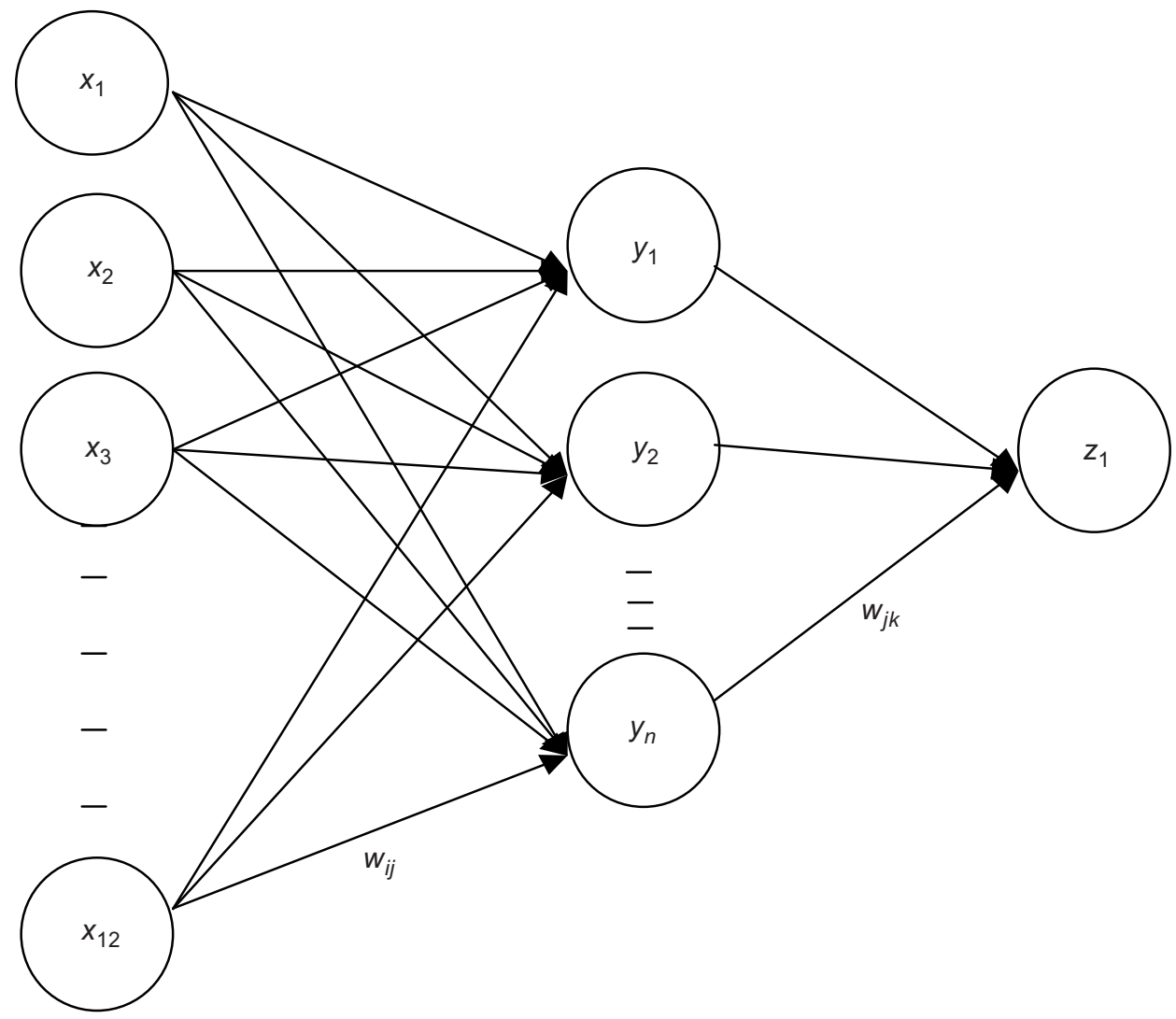

$$
\begin{aligned}
& \text { Input } \\
& \text { Layer } \\
& \left(x_{i}\right) \\
& X_{1}=\text { assembly process } \\
& X_{2}=\text { bay dimensioning } \\
& X_{3}=\text { rebar assembly } \\
& X_{4}=\text { formwork utilisation } \\
& X_{5}=\text { size } \\
& X_{6}=\text { shape } \\
& X_{7}=\text { material } \\
& X_{8}=\text { detailing } \\
& X_{9}=\text { offsite assembly } \\
& X_{10}=\text { location } \\
& X_{11}=\text { trade } \\
& X_{12}=\text { specifications }
\end{aligned}
$$

Hidden

Layer

$\left(y_{j}\right)$

\section{Output}

Layer

$\left(z_{k}\right)$

$Z_{1}=$ design constructability

Figure 1 MLP architecture 
calculation. Maximum updates means the maximum epoch of the training. Basically, the training process starts with the setting of weights and biases in the network to small random values. A training pattern is then applied to the input units and the activations of neurons in the first layer are calculated. The outputs produced by these neurons are then fed into the following layer. This process is repeated until the output in the output layer is obtained. The difference between the actual and desired output values is measured and through back-propagation process the network model connection weights are changed so that the output produced by the network becomes closer to the desired output. If the output produced by the network is larger than the desired output, the connection values are decreased. On the other hand, if the output is lower that the desired output, the connection values are increased. Training stopped when either of the two criteria is met: 1) Root Mean Square Error (RMSE) is less than 0.001 , or 2) the number of epochs reaches 10000 .

The data used in the study were divided into training, validation, and testing sets in the proportions of $70 \%, 10 \%$, and $20 \%$ respectively. Test data was not used as part of training procedures. The test data set was selected randomly from the raw data set. Validation data was used to ensure that the problem of over training the network did not take place. The ANN software that was used to train and test the samples was Neural Connection 1.0.

Table 3 The multi layer perceptron training stages

\begin{tabular}{|l|c|c|c|c|}
\hline & Stage 1 & Stage 2 & Stage 3 & Stage 4 \\
\hline $\begin{array}{l}\text { Learning } \\
\text { coefficient }\end{array}$ & 0.9 & 0.7 & 0.5 & 0.4 \\
\hline $\begin{array}{l}\text { Momentum } \\
\text { coefficient }\end{array}$ & 0.1 & 0.4 & 0.5 & 0.6 \\
\hline $\begin{array}{l}\text { Maximum } \\
\text { updates }\end{array}$ & 100 & 100 & 100 & 10000 \\
\hline
\end{tabular}

\subsubsection{Performance Measures}

The performances of each candidate models are compared based on the estimated errors between the network estimates and actual. The present study observes two types of error namely: root mean square error (RMSE) and mean absolute percentage error (MAPE). The selection of the best model is based on the error generated by each model. The model with the lowest RMSE and MAPE values is considered the best assessment model. 
RMSE is defined according to the following equation [25]:

$$
R M S E=\sqrt{\frac{\sum_{i=1}^{12}\left(T_{k}-z_{k}\right)^{2}}{n}}
$$

Where,

$$
\begin{array}{ll}
z_{k} & =\text { predicted output } \\
T_{k} & =\text { actual output } \\
n & =\text { total number of cases }
\end{array}
$$

MAPE is defined according to the following equation [3]:

$$
M A P E=\left(\sum_{i=1}^{12} \frac{\left|T_{k}-z_{k}\right|}{T_{k}} * 100 \%\right) / n
$$

Where,

$$
\begin{array}{ll}
z_{k} & =\text { predicted output } \\
T_{k} & =\text { actual output } \\
n & =\text { total number of cases }
\end{array}
$$

\subsection{RESULTS AND DISCUSSION}

Table 4 to 6 give the results of different training parameters on the performance of neural network over design constructability assessment. After experimentation with several topologies, it is found that ANNs with two layers does not result in good prediction accuracy, whereas a single hidden layer produces satisfactory results. This is consistent with other studies $[19,21,26]$ which demonstrated that no improvement could be achieved with more than one hidden layer. Determining the proper number of nodes for the hidden layer is also important as shown by the results in Table 5 where models using 3,5, and 7 hidden nodes are tested. The best performance is achieved by a network with five hidden nodes on the first hidden layer. Increasing the number of hidden nodes beyond this point produces no further improvement. This is due to the fact that too many nodes in the middle layer resulted in too many connections, thus producing a network that memorises the input data and lacks the ability to generalize the design constructability. The selection of appropriate transfer function has also significant influence on the performance of neural network as shown in Table 6. The exact shapes of the transfer functions have little impact on training speed but they may affect ultimate accuracy of the developed model. Sigmoid transfer function is found to produce better result.

The results of the study revealed that the best network has a sigmoid transfer function with 12 inputs, five hidden and one output node. The minimum RMSE and MAPE 
Table 4 Training and testing results based on number of hidden layers

\begin{tabular}{|l|c|c|c|c|c|}
\hline \multirow{2}{*}{ Model } & Hidden layer & \multicolumn{2}{|c|}{ Training } & \multicolumn{2}{c|}{ Testing } \\
\cline { 3 - 6 } & & RMSE & MAPE & RMSE & MAPE \\
\hline MLP4 & 1 & 0.6025 & 13.91 & 0.5969 & 15.17 \\
\hline MLP5 & 2 & 0.7581 & 14.12 & 0.9153 & 21.81 \\
\hline
\end{tabular}

Table 5 Training and testing results based on number of hidden nodes

\begin{tabular}{|l|c|c|c|c|c|}
\hline \multirow{2}{*}{ Model } & Hidden nodes & \multicolumn{2}{|c|}{ Training } & \multicolumn{2}{c|}{ Testing } \\
\cline { 3 - 6 } & & RMSE & MAPE & RMSE & MAPE \\
\hline MLP6 & 3 & 0.6658 & 15.15 & 0.6310 & 16.18 \\
\hline MLP7 & 5 & 0.2046 & 3.72 & 0.4078 & 10.69 \\
\hline MLP8 & 7 & 0.4096 & 9.20 & 0.5741 & 14.27 \\
\hline
\end{tabular}

Table 6 Training and testing results based on transfer function

\begin{tabular}{|l|l|c|c|c|c|}
\hline \multirow{2}{*}{ Model } & \multirow{2}{*}{$\begin{array}{c}\text { Transfer } \\
\text { function }\end{array}$} & \multicolumn{2}{|c|}{ Training } & \multicolumn{2}{c|}{ Testing } \\
\cline { 3 - 6 } & & RMSE & MAPE & RMSE & MAPE \\
\hline MLP1 & Tanh & 0.6109 & 13.83 & 0.7286 & 18.83 \\
\hline MLP2 & Sigmoid & 0.6025 & 13.91 & 0.5969 & 15.17 \\
\hline MLP3 & Linear & 0.7582 & 16.43 & 0.7511 & 19.54 \\
\hline
\end{tabular}

on the training samples are 0.2046 and $3.72 \%$ respectively. According to [18], a MAPE value of $30 \%$ is considered a reasonable evaluation while a MAPE of between 5 to $10 \%$ is considered an accurate evaluation.

Figure 2 presents results of the constructability assessment on the test samples. The calculated outputs of the test samples can be divided into two groups. Seven design projects are above the actual constructability values while eight design projects are below the actual constructability values. The range of overestimating varies from 0.42 to $25.15 \%$ with an average of $14.52 \%$. The range of underestimating varies from 0.65 to $23.6 \%$ with an average of $9.03 \%$. The overall average error for the 15 project designs is $10.69 \%$ with a standard deviation of 9.1 .

In order to verify the relationship between errors and design constructability, the assessment errors of all the samples are considered. From the results obtained, the calculated output of the samples consists of 37 sets above the actual constructability values while 33 sets are below the actual constructability values. The range of 


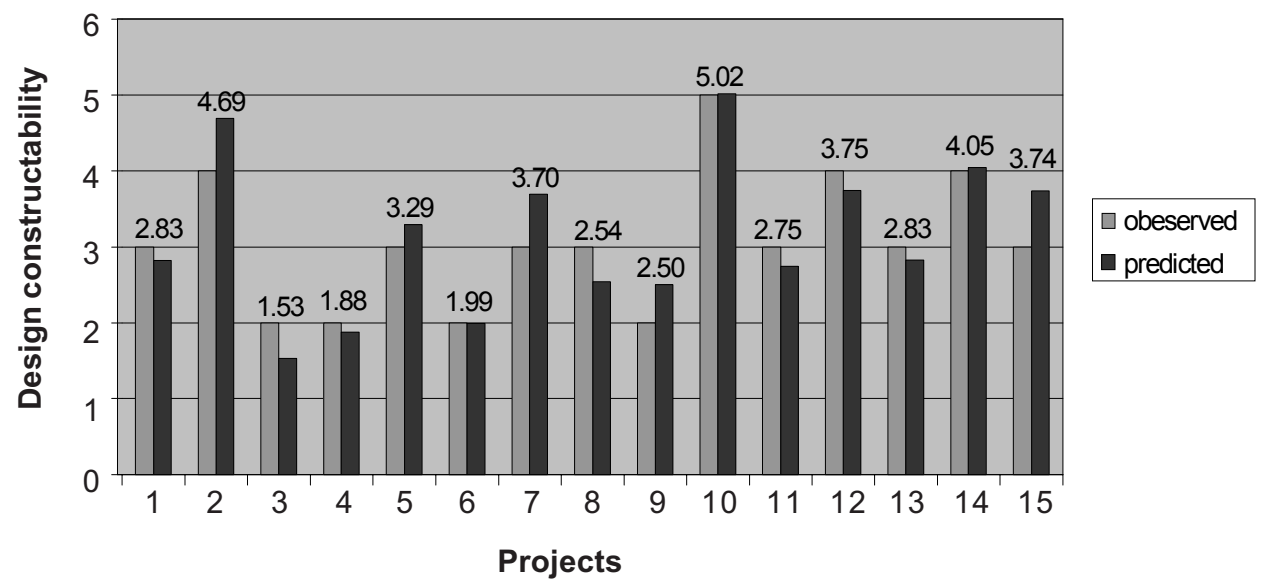

Figure 2 Design constructability (observed vs. predicted) for the ANN Model

overestimating varies from 0.10 to $25.57 \%$ with an average of $6.59 \%$. On the other hand the range of underestimating varies from 0.10 to $23.6 \%$ with an average of $5.09 \%$. The average error of all samples (70 sets) is $5.88 \%$ with a standard deviation of 7.2. Figure 3 presents regression curve between assessment error and design constructability resulting in a very low value of $\mathrm{R}^{2}$. This result indicates that assessment error is independent of the level of design constructability. However, it is dependent on factors, which have been modeled as independent variables in the network.

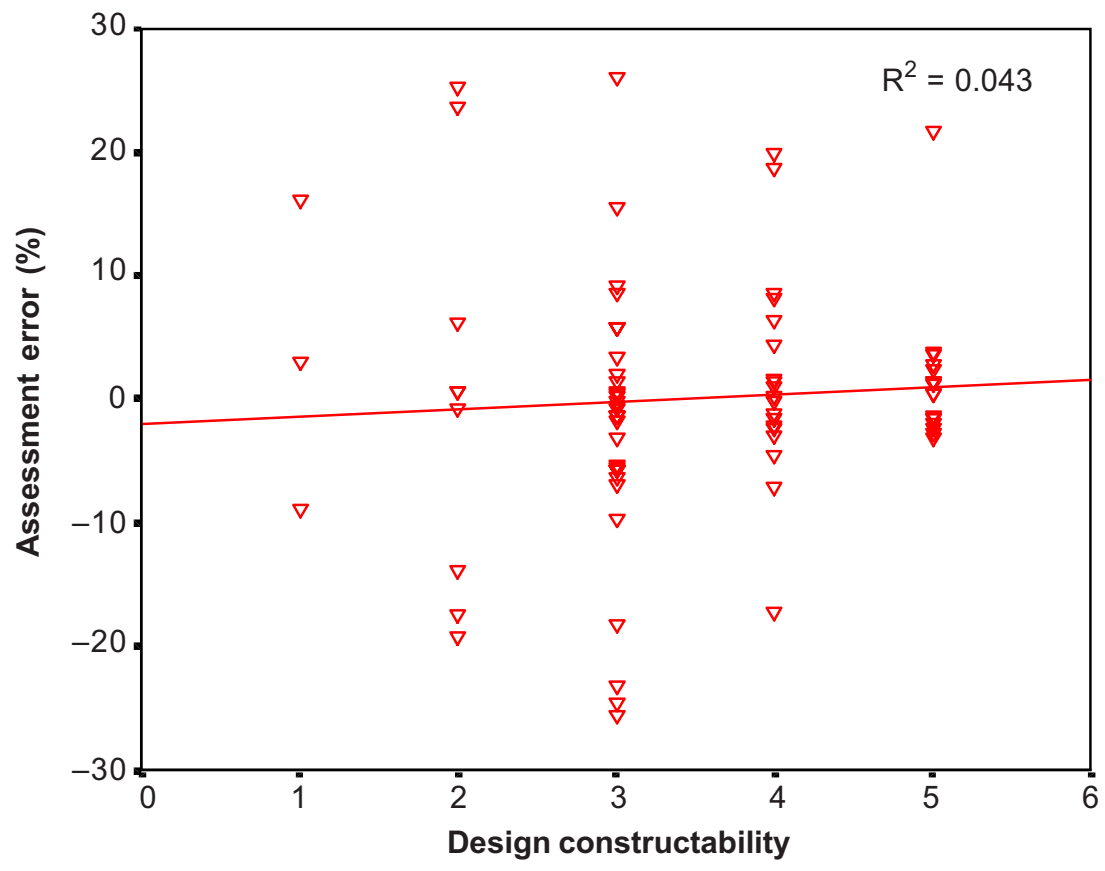

Figure 3 Variations of assessment errors with design constructability 


\subsection{CONCLUSIONS}

The development of a model to assess design constructability has been presented in this paper. The model consists of two main components i.e. the level of application of constructability factors and design constructability. The model has been developed in five main stages. It is able to optimise the design based on various aspects of constructability. The final network consists of 12 input nodes representing: 1) principle $\mathrm{P} 3$ (4 nodes); 2) principle $\mathrm{P} 4$ (4 nodes); 3) principle $\mathrm{P} 5$ (1 node); 4) principle P6 (1 node); 5) principle P14 (1 node); and 6) principle P15 (1 node). The level of design constructability represents the output node.

The 12-5-1 network gives satisfactory results on the 15 test samples where the Mean Absolute Percentage Error (MAPE) for design constructability assessment is 10.69\% with a standard deviation of 9.1. Based on the results, the network is more likely to give assessment results of higher than actual values. Since the MAPE level is quite low, it can be said that the ANN model to assess design constructability presented in this paper offers another solution to improve constructability of project design.

\section{REFERENCES}

[1] CIRIA, Buildability: An Assessment. Special Publication 26, 1983.

[2] CII, Constructability - A Primer. Publication 3-1, Construction Industry Institute, Austin, Texas, 1986.

[3] Gray, C. 1983. Buildability - the Construction Contribution. Occasional Paper 29, The Chartered Institute of Building (CIOB), Ascot.

[4] O'Connor J. T. 1985. Impacts of Constructability Improvement. Journal of Construction Engineering and Management, ASCE. 111(4): 404-410.

[5] O'Connor J. T., and R. L. Tucker. 1986. Industrial Project Constructability Improvement. Journal of Construction Engineering and Management, ASCE. 112(1): 69-81.

[6] Russell, J. S., J. G. Gugel, and M. W. Radke. 1993. Benefits and Costs of Constructability: Four Case Studies. Report 109, Department of Civil and Environmental Engineering, University of Wisconsin-Madison, Madison, Wisconsin.

[7] Mohamad Zin, R., C. W. F. Che Wan Putra, and M. Z. Abd. Majid. 2003. A Framework for the Assessment of Design Constructability, $2^{\text {nd }}$. International Conference on Innovation in Architecture, Engineering and Construction, Loughbrough, UK.

[8] Navon, R., and A. Shapira. 2000. Automated Rebar Constructability Diagnosis. Journal of Construction Engineering and Management, ASCE. 126(5).

[9] Skibniewski, M., A. Arciszewski, and K. Luaprasert. 1997. Constructability Analysis: Machine Learning Approach. Journal of Computing in Civil Engineering, ASCE. 11(1).

[10] Fischer, M., AND C. B. Tatum. 1997. Characteristic of Design Relevant Constructability Knowledge, Journal of Construction Engineering and Management, ASCE. 123(3).

[11] Alshawi, M., and J. Underwood. 1994. A Process and An Object Oriented Analysis to Integrate Design and Construction. Proceedings of CIB W78 Workshop on Computer Integrated Construction.

[12] Malek, M. 2000. An Application of Fuzzy Modelling in Construction Engineering. Associated School of Construction - Proceedings of Annual Conference.

[13] Fischer, M., and F. Aalami. 1994. Model Based Constructability Analysis: The Moca System. Proceedings of CIB W78 Workshop on Computer.

[14] Buildable Design and Appraisal System. Building and Construction Industry of Singapore, $4^{\text {th }}$ Edition, 2000.

[15] CIIA, Constructability Principles File. Construction Industry Institute Australia, University of South Australia, Adelaide, 1993. 
[16] Rosli Mohamad Zin, Che Wan Fadhil Che Wan Putra, and Muhd. Zaimi Abd. Majid. 2002. Constructability Improvement of Project Designs. Proceedings of National Seminar on Civil Engineering (AWAM 2001), Universiti Sains Malaysia, Pulau Pinang.

[17] Arditi, D., and O. B. Tokdemir. 1999. Comparison of Case-based Reasoning and Artificial'. Journal of Computing in Civil Engineering. ASCE. 13(3): 162-169.

[18] Sobri Harun. 1999. Simulation and Forecasting of Net Inflows for Reservoir Operation and Management. Ph.D. Thesis. Universiti Teknologi Malaysia.

[19] Cheung, S. O., C. M. Tam, and F. C. Harris. 2000. Project Dispute Resolution Satisfaction Classification Through Neural Network. Journal of Management in Engineering. ASCE. 16(1): 70-79.

[20] Sinha, K. S., and A. R. McKim. 2000. Artificial Neural Network for Measuring Organisational Effectiveness. Journal of Computing in Civil Engineering. 14(1).

[21] Ogunlana, O.S., Bhokha, S., and N. Pinnemitr. 2001. Application of Artificial Neural Network (ANN) to Forecast Construction Cost of Buildings at the Pre-design Stage. Journal of Financial Management of Property and Construction. 6(3).

[22] Muhd. Zaimi Abd. Majid and Noor Yasmin Zainun. 2002. Technique to Develop Needs Model on Housing for Low Income Groups: a Literature and Malaysia Experience. Proceedings of the $2^{\text {nd. }}$ International Conference on Systems Thinking in Management, 3-5 April. Salford, UK. A3-28.

[23] Khairulzan Yahya. 2002. An Evaluation to Neural Netwotk Model Ability to Predict Low Cost Housing Demand In Urban Areas In Selangor. M.Sc. Thesis. Universiti Teknologi Malaysia.

[24] Lippmann, P. R. 1987. An Introduction to Computing with Neural Nets. IEEE ASSP Magazine. 4(2).

[25] Plaut, D., S. nOWLAN, AND g. e. Hinton. 1986. Experiments on Learning by Backpropagation. Technical Report CMU-CS-86-126. Department of Computer Science, Carnegie Mellon University, Pittsburgh.

[26] Boussabaine, A. H., and T. M. S. Elhag. 1999. Tender Price Estimation Using ANN Methods. Research Report No. 3, Construction Cost Engineering Research Group, School of Architecture \& Building Engineering, University of Liverpool.

[27] SPSS Inc. 1995. Neural Connection 1.0 Users' Guide. Chicago. Illinois. 